\title{
Some of the Physical Properties of UV Jet Printed Furniture Surfaces
}

\section{Neka fizikalna obilježja površine namještaja obrađene UV printanjem}

\author{
Preliminary paper • Prethodno priopćenje \\ Received-prispjelo: 6. 2. 2012. \\ Accepted-prihvaćeno: 15. 11. 2012. \\ UDK: $630 * 812 ; 630 * 832.281 .1$ \\ doi:10.5552/drind.2013.1203
}

\begin{abstract}
This study researches some physical properties of furniture surfaces on which UV jet printing is applied. To this end, UV protected digital printing ink was applied on melamine faced chipboard (MFC) and Printpan (Pp) panels and their surface resistance to cold liquids (TS 12720), hot liquids (TS 4980), dry heat (TS EN 12722), wet heat (TS EN 12721), water vapor (TS EN 438-2), glowing cigarette (TS 4756), and abrasion (TS 4755) was identified. As a result, it was found that UV jet printing ink applied on melamine faced chipboard and printpan panels is not resistant to cold liquid, water vapor, glowing cigarette and abrasion but relatively resistant to hot liquid, dry heat and wet heat.
\end{abstract}

Keywords: UV jet printing method, UV curable digital printing ink, melamine faced chipboard, printpan, physical properties

SAŽETAK • U radu se prikazuju rezultati istraživanja nekih fizikalnih obilježja površine namještaja obrađene UV printanjem. Zaštitno UV digitalno printanje primijenjeno je na pločama ivericama (MFC) i printpan pločama (Pp) te je ispitana otpornost njihove površine na hladne tekućine (TS 12720), vruće tekućine (TS 4980), suho zagrijavanje (TS EN 12722), vlažno zagrijavanje (TS EN 12721), vodenu paru (TS EN 438-2), upaljenu cigaretu (TS 4756) i abraziju (TS 4755). Rezultati su pokazali da površine ploča iverica s melaminskom folijom i printpan ploča obrađenih UV printanjem nisu otporne na hladne tekućine, vodenu paru, upaljenu cigaretu i abraziju, a relativno su otporne na vruće tekućine, suho zagrijavanje i vlažno zagrijavanje.

Ključne riječi: metoda UV printanja, UV tinta za digitalno printanje, ploča iverica s melaminskom folijom, printpan, fizikalna obilježja

\section{INTRODUCTION \\ 1. UVOD}

Today in furniture industry, particularly in mass production modular furniture systems, the pre-coated wooden composite boards are mostly being used. The main reason for using these boards is that they have already been coated or painted, and hence there is no need for coating and finishing processes in furniture manufacturing processes. Therefore, it is possible to reach higher productive capacities with lower investments. The melamine impregnated paper, plastic coatings and paint systems are most commonly used as surfacing material in these boards (Istek et al., 2010).

\footnotetext{
${ }^{1}$ Author is assistant professor at Faculty of Technical Education, Department of Furniture and Decoration Education, Karabuk University, Karabuk, Turkey. ${ }^{2}$ Author is lecturer at Yozgat Vacational School, Bozok University, Yozgat, Turkey.

Autor je docent Fakulteta tehničkog obrazovanja, Odjel obrazovanja o namještaju i opremanju, Sveučilište u Karabuku, Karabuk, Turska.

${ }^{2}$ Autor je predavač Yozgat strukovne škole, Sveučilište Bozok, Yozgat, Turska.
} 
The most commonly used chipboard is the one coated with melamine impregnated paper (MFC). Painted chipboards $(\mathrm{Pp})$, known as printpan in the market, whose surfaces are painted straight and figured with the direct press technique, have recently been increasingly used in furniture industry.

As furniture is also a product of fashion, boards with a large variety of surface colors and figures are produced in order to meet the taste of different consumers. Due to costumer oriented marketing approach, rapidly changing tastes and tough competitive conditions, it is necessary to meet the needs of all consumers. However, board production technology and economic factors do not enable a great variety of figures and production in little amounts in these wooden composite materials (Chapman, 2006). To solve this contradiction, producers searched for different solutions and digital printing technology started to be used in furniture industry. Digital printing method could be implemented swiftly and a wide variety of colors and figures could be used. With the development of ultraviolet (UV) curable digital printing ink, this technology has been used more widely. The use ranges from press and advertisements to textiles, handcrafts and even furniture industry. It is preferred as it can be applied to every kind of surface regardless of material and shape, which enables quick production, and provides high quality in terms of image and aesthetics. This method, also called "green technology", is preferred because its harmful environmental effects are very few particularly with the use of entirely UV curable inks that make no use of harmful volatile solvents. (Işmal, 2003).

UV curable digital printing ink used in press technologies gives a decorative value to the surface although it does not constitute a layer such as paint or varnish. This ink, which replaces the other common upper surface applications, is the best material that one can possibly desire or dream of. By means of this printing method, every picture could be applied on furniture surfaces. For decorative purposes, it is used on cupboard doors and on parts where visual aesthetics are required. With this technology, all kinds of customer needs can be met at very short notice and tailor made furniture can be produced, at the satisfaction of customers.

Developments in technology and science enable the production of new materials, and all new materials should go through a performance test in order to determine their area of use. For manufacturers, it is important to use the right material in the right place; and for endusers it is important to know the properties and limits of the material in order to use them properly. In order to prevent the consumers and country economy to suffer a loss, some upper surface tests are applied to see the resistance of furniture surfaces against the effects they could be exposed to. This can give the answer to the questions such as: "Which material can be used in which area? and "What kind of effects it can resist?"

Several studies were carried out to examine surface resistance of wood finishes to dry heat, wet heat, glowing cigarette, abrasion and scratch (Sönmez, 1989; Kaygın, 1997; Örts et al., 2002; Budakçı et al., 2009) but this is not the case with printed inks. Akgün (2008) has surveyed the dry film thicknesses, glossiness, hardness, and surface resistances to cold liquids of UV varnish with nanoparticles and conventional varnish layers. It has been shown that the UV varnish system is the most durable kind of varnish against all the liquids used in the study. Although there are some studies in the literature particularly in the field of typography, no academic study on UV jet printing technology applied on furniture surfaces has been found.

The aim of this study is to determine the surface performances of melamine faced chipboard and printpan surfaces, on which the new UV jet printing technology was applied, and their resistance to some physical effects.

\section{MATERIALS AND METHODS 2. MATERIJALI I METODE}

\subsection{Materials}

2.1. Materijali

In this study, melamine faced chipboard (MFC) and painted panel ( $\mathrm{Pp}$ ) (Printpan) have been used as wooden based substrate to make digital printing over. Boards are supplied from Kastamonu Entegre INC. The cream colored melamine faced chipboard, used as test specimen, has the thickness of $8 \mathrm{~mm}$ and density of $0.8 \mathrm{~g} / \mathrm{cm}^{3}$. The cream colored Printpan board has the thickness of $8 \mathrm{~mm}$ and density of $0.7 \mathrm{~g} / \mathrm{cm}^{3}$.

Blue colored UV curable digital printing ink (Sericol ZN 001) is used in the printing process.

For determining the resistance of surfaces to cold liquids, $96 \%(\mathrm{v} / \mathrm{v})$ ethanol, $10 \%(\mathrm{~m} / \mathrm{m})$ acetic acid, acetone, milk and olive oil were used in accordance with TS EN 12720 standards. For determining the resistance of surfaces to hot liquids, tea $\left(92.5^{\circ} \mathrm{C}\right)$, instant coffee $\left(94{ }^{\circ} \mathrm{C}\right)$ and distilled water $\left(98^{\circ} \mathrm{C}\right)(\mathrm{TS} 4980)$ were used.

\subsection{Methods \\ 2.2. Metode}

4 pieces of flat surfaces sized $50 \times 100 \mathrm{~cm}$ were cut from each of the $8 \mathrm{~mm}$ thick melamine coated chipboard and printpan panels and these pieces were acclimatized for a week at the temperature of $23 \pm 2{ }^{\circ} \mathrm{C}$, and $50 \pm 5 \%$ relative humidity. Average surface roughness ( $R \mathrm{a})$ of the boards was measured by using TR200 roughness tester. Twenty random measurements of the surface of each board were taken at a tracing speed of $1.5 \mathrm{~mm} / \mathrm{s}$ over $200 \mathrm{~mm}$ span. Average surface roughness of the MFC and Pp panels were measured as 5.028 $\mu \mathrm{m}$ and $6.459 \mu \mathrm{m}$, respectively. After that, two layers of UV curable digital printing ink were applied on melamine faced chipboard and printpan surface in Zünd UVjet 215-plus digital printing machine. Thicknesses of the panels were measured before and after printing by using digital micrometer with the sensitivity of $0.001 \mathrm{~mm}$. Thirty random measurements of each board were taken and the result of these measurements showed that the ink layer thickness on the MFC was $0.03 \mathrm{~mm}$ and the ink layer thickness on Pp was 0.01 
$\mathrm{mm}$. Specimens were cut off from these pieces in required measures and used for each experiment.

The resistance of experiment sample surfaces to cold liquids (TS 12720), hot liquids (TS 4980), dry heat (TS EN 12722), wet heat (TS EN 12721), water vapor (TS EN 438-2), glowing cigarette (TS 4756) and abrasion (TS 4755) was determined in accordance with the relevant standards.

\section{RESULTS AND DISCUSSION}

3. REZULTATI I RASPRAVA

\subsection{Surface resistance to cold and hot liquids}

\subsection{Otpornost površine na hladne i vruće tekućine}

The changes that cold and hot liquids made on sample surfaces reveal differences depending on the kind of material, kind of liquid, and the $\mathrm{pH}$ value of the liquid. The change of surface impact categories depending on the kind of liquid are given in Figure 1. Based on the obtained data, when MFC and UV jet printing was applied on printpan (Pp-UV), surfaces have shown the best surface performance against cold test liquids applied to the surfaces, confirming that MFC-UV is the least durable surface. The durability of melamine faced clipboard is the result of the fact that the melamine resin on the board surface is resistant to liquids due to its hydrophobic character. The reason of low durability of MFC-UV surface might be that the liquids that remained on the surface, not being able to penetrate into the material due to the hydrophobic character of MFC surface, deform the structure of the ink and lead to further distortion. Acetic acid has led to the utmost distortion of surfaces. Being a good solvent due to its acidic character (Hakdiyen, 1972), acetic acid has led to dramatic distortion.

The changes that hot liquids made on sample surfaces reveal differences depending on material and liquid type (Figure 1). While it is confirmed that Pp-UV and MFC surfaces are the most durable surfaces against hot liquids, it is determined that Printpan is the least durable surface. The reason for Pp-UV surface to be more resistant than the Printpan surface might be that Printpan material absorbs the liquid and the remaining liquid has less strong effect on the ink layer. Since the melamine resin on the MFC surface is hydrophobic and resistant to heat (Sönmez and Budakçı, 2004), it can be concluded that MFC shows the best performance against hot liquids.

\subsection{Surface resistance to dry and wet heat}

3.2. Otpornost površina na suho i vlažno zagrijavanje

The resistance of surfaces to dry and wet heat in terms of material type is given in Figure 2. In the classification of surfaces, the temperature is determined at which they take the highest evaluation category value 5 .

The resistance temperature of Printpan surface against dry heat is $100{ }^{\circ} \mathrm{C}$, of PP-UV and MFC-UV surface it is $120^{\circ} \mathrm{C}$ and of MFC it is $140{ }^{\circ} \mathrm{C}$. It can be stated that the resistance of UV curable ink to dry heat is $120^{\circ} \mathrm{C}$. MFC surface has shown the utmost surface performance against dry heat. The reason for this is that the melamine formaldehyde resin is resistant to heat up to $130{ }^{\circ} \mathrm{C}$ (Whelan, 1994).

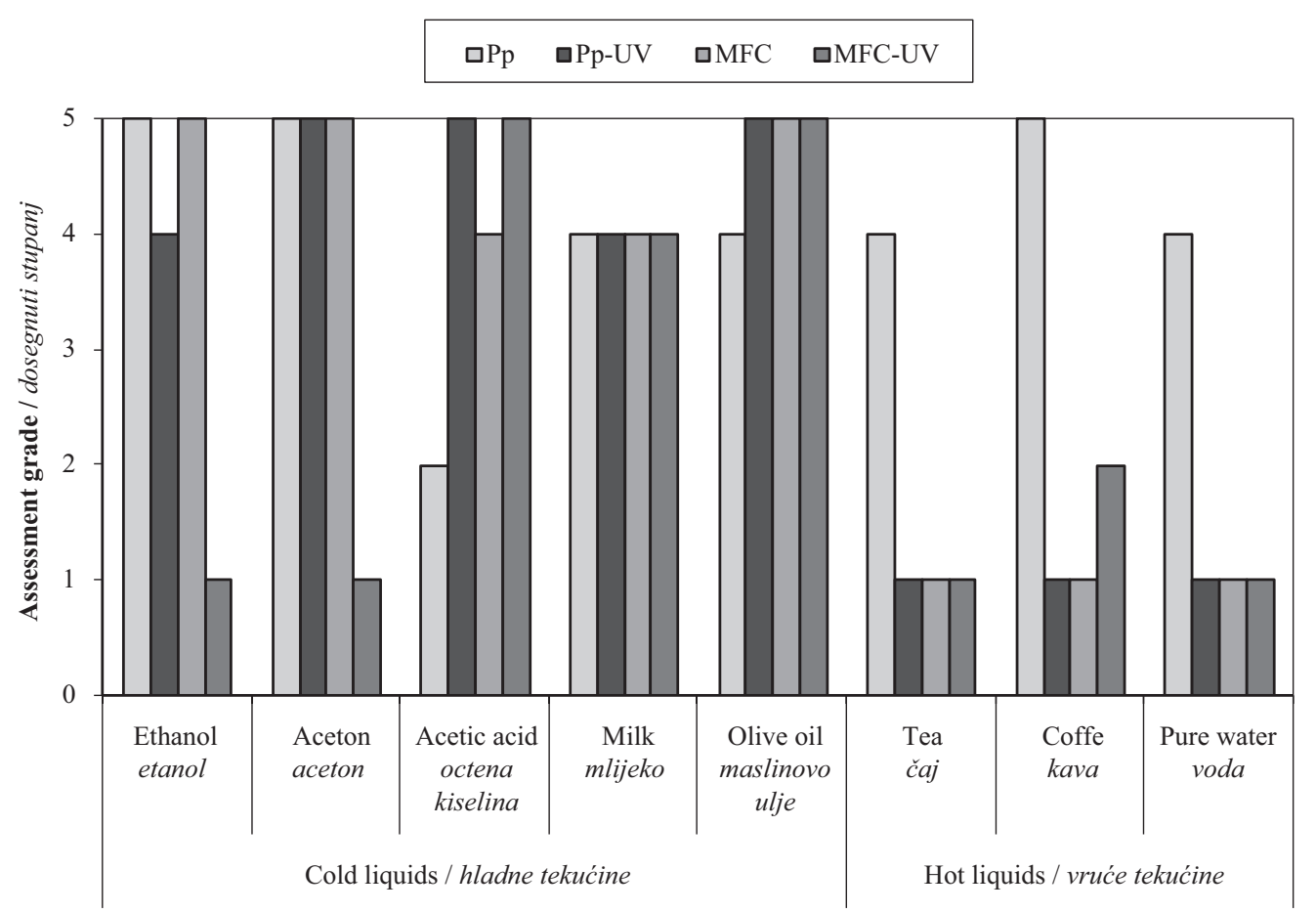

Figure 1 Surface resistance to cold and hot liquids in terms of material and liquid type (Pp - Printpan, Pp-UV - UV printed printpan, MFC - Melamine faced chipboard, MFC-UV - UV printed MFC; surface impact category number 5 indicates that it is the most durable surface)

Slika 1. Otpornost površina na različite hladne i vruće tekućine ( $\mathrm{Pp}$ - printpan ploča, $\mathrm{Pp}-\mathrm{UV}$ - UV printana ploča, MFC ploča iverica s melaminskom folijom, MFC-UV - UV printana MFC; ocjena 5 označava površine najbolje otpornosti) 


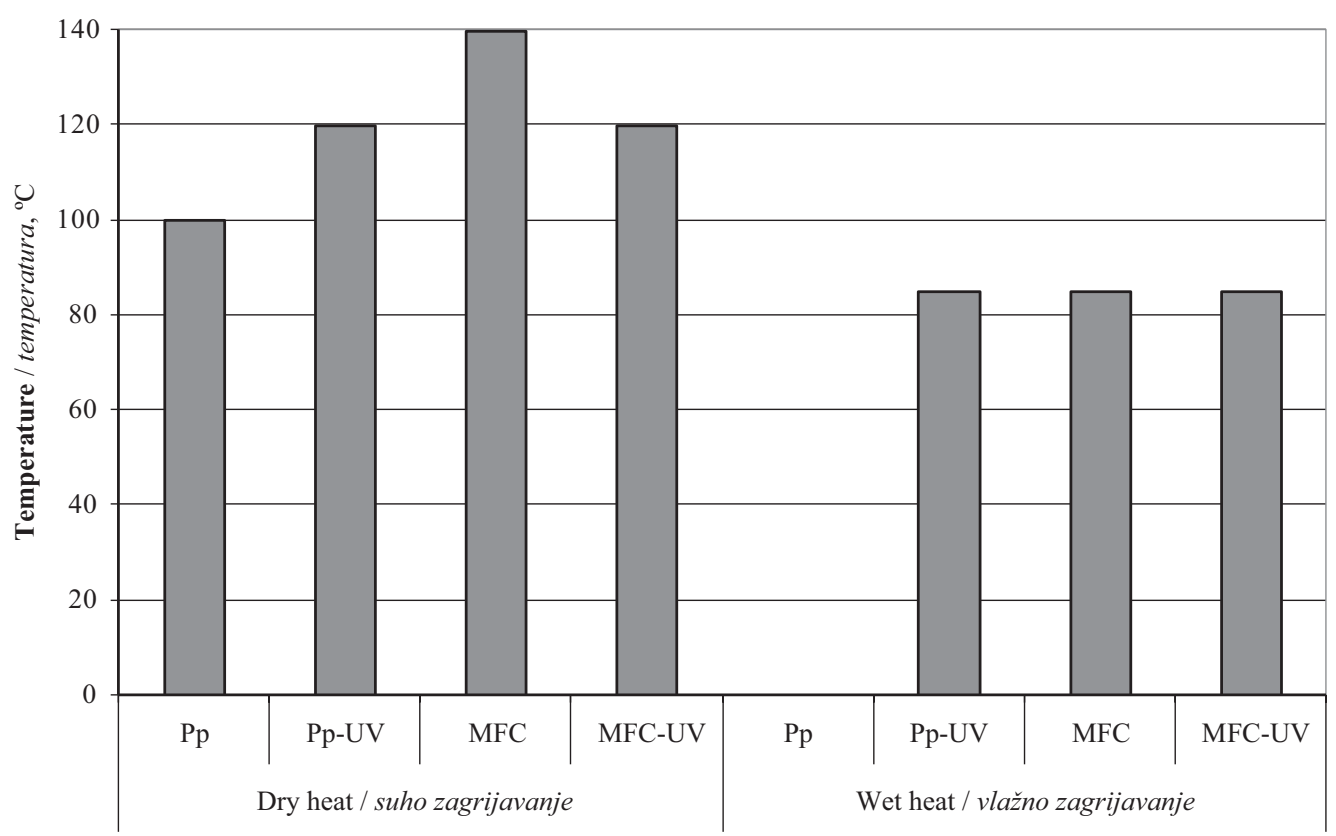

Figure 2 The resistance of surfaces to dry and wet heat in terms of material type

Slika 2. Otpornost površina na suho i vlažno zagrijavanje

It is determined that the Pp surface is the least durable surface regarding its resistance to wet heat. There is no value shown in Figure 2 because Pp surface falls into the lowest resistance category even at the lowest temperature $\left(55^{\circ} \mathrm{C}\right)$ specified in the standard. It is shown that other surfaces are rather more durable $\left(85^{\circ} \mathrm{C}\right)$ than Printpan surface. It can be argued that distortion originated because melting occurred on the acrylic paint surface within the thermoplastic structure used in the Printpan surface. Due to the relatively lower water absorption of the other surfaces, it can be argued that the heat had hardly any impact on the material and, therefore, the distortionary effect occurred in rather high temperatures.

\subsection{Surface Resistance to water vapor \\ 3.3. Otpornost površina na vodenu paru}

Pp-UV and MFC-UV surfaces have fallen into the weakest impact category (grade 1) being unable to show any resistance to water vapor. It can be asserted that distortion occurred on the surface as the digital printing ink was not durable against water and heat. The results of abrasion experiment that was conducted (see section 3.5) also reveal that ink could not be sufficiently adsorbed by the surfaces and that the adhesion strength was low, hence, in this situation, the steam might have led to distortions on the surface by having a higher impact in between the material and the ink. It is shown that $\mathrm{Pp}$ and MFC surfaces are relatively more resistant to water vapor (grade 2) than the other two surfaces.

\subsection{Surface resistance to glowing cigarette}

3.4. Otpornost površina na upaljenu cigaretu

Glowing cigarette shows similar impacts on sample surfaces. Since glowing cigarette leads to carbonization on $\mathrm{Pp}, \mathrm{Pp}-\mathrm{UV}$ and MFC-UV surfaces, it is determined that these surfaces fall into the least durable surface category (grade 1). It is detected that MFC sur- face is relatively more durable against glowing cigarette (grade 2). Browning and explicit marks have occurred on MFC surface. This happened because the melamine resin on the surface is more resistant to heat than paint on the surface of Pp or the ink (Whelan, 1994). The reason for carbonization on other surfaces is because the UV dried digital print ink and paint on printpan surface are not resistant to fire. This is an expected result as the temperature of the tip of a glowing cigarette is approximately $288^{\circ} \mathrm{C}$ (Smith et al., 2008) and this temperature caused damage on the surface of the boards.

\subsection{Abrasive resistance}

3.5. Otpornost na abraziju

The results of abrasion experiment showed that MFC is more durable than the other surfaces. While $\mathrm{Pp}, \mathrm{Pp}-\mathrm{UV}$ and MFC-UV corroded after 25 cycles, MFC corroded after 300 cycles. The basic requirement for durable coating performance on the surface of wood-based panels is a good adhesion between the panel surface and the coating material (Istek et al., 2012). It is possible to say that since UV ink and paint on Printpan surface cannot penetrate into the panel adequately and since their adhesion strength is low (Walker and Lindström, 2010), they are not resistant to abrasion.

\section{CONCLUSION}

\section{ZAKLJUČAK}

- It is determined that, although Pp, Pp-UV and MFC surfaces show minor changes regarding the resistance to cold liquids in terms of reactive type, they are durable in general terms and that MFC-UV surface is relatively less durable.

- It is established that Pp-UV, MFC and MFC-UV surfaces are durable against hot liquids while $\mathrm{Pp}$ surface is not durable. 
- It is indicated that the Pp surface is not durable against wet heat and that the resistance of other surfaces to wet heat is $85{ }^{\circ} \mathrm{C}$. It is specified that the surfaces are relatively more durable against dry heat $\left(120^{\circ} \mathrm{C}\right)$.

- It is detected that all the surfaces are not resistant to water vapor and glowing cigarette.

- While MFC surface is more durable against abrasion, it is confirmed that because of low adhesion strength of UV curable ink, the other surfaces are not durable.

As a result, since the UV curable ink is not very durable, it is advised that it should not be used in productions where it could be exposed to strong chemicals (table, desk, etc.) and in places, such as bathrooms, etc., where it could be exposed to water vapor. In these environments, it could be used by applying varnish as a protective layer. To this end, water based varnish could be used. When cleaning the products in which UV curable digital printing ink has been used, strong cleansers should not be used. Since the digital printing ink applied on printpan surface would show better performance, the use of printpan as substrate and for decorative purposes on cupboard doors would be convenient.

\section{REFERENCES}

5. LITERATURA

1. Akgün, E., 2008: Comparison of conventional varnishes with nanolacke UV varnish with respect to resistance properties, M.Sc.Thesis, p.1, Zonguldak Karaelmas University, Zonguldak.

2. Budakçı, M.; Sönmez, A.; Esen, R., 2009: Investigation the resistance of wooden varnishes to steam and wet heat. 5. International Advanced Technologies Symposium (IATS'09), 13-15 May 2009, Karabük, Turkey.

3. Chapman, K. M., 2006: "Wood-based panels: particleboard, fibreboards and oriented strand board" Primary Wood Processing, 2nd Ed, Walker, J.F., Springer, The Nederlands, pp. 427-475.

4. Hakdiyen, I., 1972: General and Technical Chemistry, Text Book, Birsen Bookstore Publications, Istanbul, pp. 263-268.

5. Istek, A.; Aydemir, D.; Aksu, S., 2010: The effect of decor paper and resin type on the physical, mechanical, and surface quality properties of particleboards coated with ipregnated decor paper. BioResources 5(2): 1074-1083.

6. Istek, A.; Aydemir, D.; Eroglu, H., 2012: Surface properties of mdf coated with calcite/clay and effects of fire retardants on these properties. Maderas. Ciencia y tecnología, 14(2): 135-144.

7. Işmal, Ö. E., 2003: Textile Digital (Ink jet) Printing Technologies Basic Principles and Development Process.
Turkish Textiles Foundation Publications No: 2, pp. $65-$ 66, Meta Press Publication Services, Izmir.

8. Kaygın, B., 1997: Durability properties of opaque paints used on wooden surfaces. M.Sc. Thesis, p. 97, Zonguldak Karaelmas University, Zonguldak.

9. Örs, Y.; Küreli, I.; Söğütlü, C., 2002: The determine of the abrasive and scratching strengths of various wood materials used for kitchen workbench tables in residences. Gazi Üniversity Journal of Science 15(2): 475-484.

10. Smith, E.; Christopherson, J.; Adams, G.L., 2008: The Wood Shake and Shingle Roof Hazard. University of Nevada Cooperative Extension Fact Sheet 94-26.

11. Sönmez, A., 1989: Durability of varnishes used on surfaces of wooden furniture against important physical mechanical and chemical effects. Ph.D. Thesis, p. 92, Gazi University, Ankara.

12. Sönmez, A.; Budakç1, M., 2004: Finishing processes in woodworks II., Gazi University Faculty of Technical Education, Ankara, pp. 25-27.

13. ***TS 4755. 1986: Furniture Surfaces- Determination of Abrasive Resistance. T.S.E., Ankara, pp. 1-4.

14. ***TS 4756. 1986: Furniture Surfaces- Determination of Resistance to Glowing Cigarette. T.S.E, Ankara, pp. 1-2.

15. ***TS 4980. 1986: Furniture Surfaces- Determination of Resistance to Hot Liquid. T.S.E, Ankara, pp. 1-3.

16. ***TS EN 12720. 2002: Furniture - Assessment of surface resistance to cold liquids. T.S.E., Ankara, pp. 1-7.

17. ${ }^{* * *}$ TS EN 12721. 2002: Furniture - Assessment of surface resistance to wet heat. T.S.E., Ankara, pp. 1-7.

18. ***TS EN 12722. 2002: Furniture - Assessment of surface resistance to dry heat. T.S.E., Ankara, pp. 1-8.

19. ***TS EN 438-2. 2007: High-pressure decorative laminates (HPL) - Sheets based on thermosetting resins (usually called laminates) - Part 2: Determination of properties, T.S.E., Ankara, pp. 14-16.

20. Walker, P.; Lindström, M., 2010: UV-Curable Large Format Printers: Technology Test \& Guide. Digital Dots Special Report, Digital Dots Ltd., UK.

21. Whelan, T., 1994: Polymer Technology Dictionery. Chapman \& Hal, London, p. 242

http://dx.doi.org/10.1007/978-94-011-1292-5.

\section{Corresponding author:}

Assistant Professor SUAT ALTUN

Karabuk University

Faculty of Technical Education

Department of Furniture and Decoration Education

100. Y11, 78050, Karabuk

TURKEY

e-mail: saltun@karabuk.edu.tr 